\title{
KETERAMPILAN BERBAHASA ARAB DENGAN PENDEKATAN KOMPREHENSIF
}

\author{
Lady Farah Aziza, Ariadi Muliansyah \\ PBA FITK UIN Sunan Kalijaga Yogyakarta \\ ladyfarahaziza16@gmail.com, ariadimuliansyah@gmail.com
}

\begin{abstract}
Comprehensive approach in teaching is a further implementation of the teaching plan that covers teaching procedure in detail. This research aim to explore said comprehensive approach for Arabic language teaching that focused in developing the four skills: listening (maharat al-istima'), speaking (maharat al-kalam), reading (maharat al-qira'at), and writing (maharat al-kitabah). This comprehensive approach consists of four steps: orientation, exploration, strengthening, and summarizing. Orientation is the first step in the teaching process that encourages students to focus their study on the subject presented. Exploration is the next step in the process that encourages students to be active in finding the facts, problems, and its solutions. Strengthening step is the process of deepening, broadening, and strengthening the students' skill and mastery of the subject obtained in the exploration step. The last step is summarizing, encourages the students to present and summarize the subject they studied.
\end{abstract}

Key words: Arabic language skills, comprehensive approach

\begin{abstract}
Abstrak: Pembelajaran dengan pendekatan komprehensif merupakan langkah implementasi darirencana pembelajaran terpadu secara menyeluruh, berisi rincian dari prosedur pembelajaran. Penelitian ini bertujuan untuk mengungkapkan bagaimana pendekatan komprehensif dalam pembelajaran bahasa Arab yang difokuskan untuk meningkatkan keterampilan berbahasa Arab, seperti keterampilan mendengar (Maharat al-Istima'), keterampilan berbicara (Maharat al-Kalam), keterampilan membaca (Maharat al-Qira'at), keterampilan menulis (Maharat al-Kitabah). Ada empat langkah utama dalam pendekatan komprehensif ini yaitu, langkah orientasi, eksplorasi, pemantapan dan penyimpulan. Langkah orientasi atau kegiatan awal pembelajaran merupakan langkah untuk mendorong kelas memusatkan perhatian terhadap pembelajaran; langkah eksplorasi adalah langkah untuk mengajak dan mendorong siswa untuk mencari dan menemukan fakta, pengetahuan, masalah dan pemecahan; langkah pemantapan merupakan langkah memperdalam, memperluas, memantapkan, memperkuat penguasaan materi dan kemampuan yang telah dicapai pada langkah eksplorasi; dan langkah penyimpulan adalah langkah untuk menyimpulkan tentang apa yang telah dipelajari.
\end{abstract}

Kata Kunci: keterampilan berbahasa Arab, pendekatan komprehensif. 


\section{A. Pendahuluan}

Bahasa Arab merupakan salah satu bahasa asing yang belakangan ini banyak ditekuni oleh masyarakat untuk dipelajari dan ditelaah, baik yang berorientasi pada pendekatan normatif dan spiritualis dengan berkeyakinan bahwa bahasa Arab merupakan bahasa agama karena Al-Qur'an diturunkan dengan bahasa Arab, maupun melaui pendekatan edukatif dan konsumtif, yang beranggapan bahwa bahasa Arab merupakan bahasa yang patut dikaji secara mendalam untuk mengetahui kajian historis dan estetikanya. ${ }^{1}$

Bahasa pada prinsipnya digunakan oleh para pemakainya sebagai pembawa pesan yang ingin disampaikan kepada orang lain. Kebutuhan pemakai bahasa adalah agar mampu merujuk objek ke dunia nyata, misalnya mampu menyebutkan nama, keadaan, peristiwa dan ciri-ciri benda dengan kata-kata tersebut ke dalam kalimat-kalimat sehingga ia mampu menyusun proposisi yaitu rangkaian kata yang membentuk prediksi tentang benda, orang atau peristiwa. ${ }^{2}$

Sesuai Permenag RI nomor 02 tahun 2008, mata pelajaran bahasa Arab di madrasah ibtida'iyah sudah mulai diajarkan kepada siswa sejak kelas IV - VI. Dalam Standar Kompetensi (SK) pembelajaran bahasa Arab di madrasah ibtidaiyah sudah terpetakan menjadi empat SK yaitu: kemampuan mendengar, berbicara, membaca, dan menulis. Realitasnya, dari keempat kemampuan tersebut yang paling dominan hanya kemampuan pasif (membaca dan menulis) dari pada kemampuan aktif (mendengar dan berbicara). ${ }^{3}$

Hanya saja dari keempat komponen tersebut, permasalahan yang sering muncul dalam pembelajaran bahasa Arab di madrasah dan sekolah lainnya yang memasukkan mata pelajaran bahasa Arab adalah lemahnya kemampuan siswa dalam berbahasa Arab pasif terlebih kemampuan bahasa Arab aktif. Hal ini dikarenakan guru kurang menguasai materi pembelajaran dan pengetahuan tentang strategi pembelajaran, metode, media atau pun permainan bahasa.

Berdasarkan uraian tersebut, penulis tertarik dalam meneliti pembelajaran keterampilan berbahasa Arab dengan pendekatan komprehensif. Dengan harapan penelitian ini bisa menemukan solusi dari permasalahan akademik bagi pelajar bahasa Arab, yaitu lemahnya kemampuan siswa dalam berbahasa Arab pasif, dan lebih lemah lagi dalam berbahasa Arab aktif.

1 Taufik, Pembelajaran Bahasa Arab MI (metode aplikatif dan inovatif berbasis ICT),,(Surabaya: PMN, 2011), hal. 1

22 Furqonul Aziz, et 1, Pengajaran Bahasa Komunikatif, (Bandung: Remaja Roesda Karya, 1996), 10

3 Taufik, op.cit, hal. 109 


\section{B. Landasan Teori}

\section{Pembelajaran Bahasa Arab}

Pembelajaran merupakan sebuah proses yang mencakup dua hal: seorang guru mengajarkan pengetahuan kepada anak didik untuk mempelajari suatu pengetahuan. Dalam bahasa Inggris, "to teach" menunjuk arti: memperlihatkan sesuatu kepada seseorang melalui tanda atau symbol; penggunaan tanda atau simbol dengan maksud membangkitkan atau menumbuhkan respon mengenai kejadian, seseorang, observasi, penemuan, dan lain sebagainya. ${ }^{4}$

Dalam bahasa Arab, pengajaran atau pembelajaran diistilahkan dengan ta'lim, mashdar dari 'allama. Akar katanya, 'alima, berarti "mengetahui'atau "mengerti".5 Ta'lim berarti suatu kegiatan yang menunjukkan penyampaian pengetahuan yang sedang dilakukan di dalam kelas dengan menggunakan berbagai media pembelajaran. ${ }^{6}$

Bahasa Arab adalah bahasa yang digunakan oleh bangsa-bangsa Arab dan masyarakat Islam. Ia merupakan life language yang kuat, mengalami perkembangan, dan mampu menerjemahkan bahasa Perancis, India, Yunani dan sebagainya. Bahasa Arab di abad pertengahan merupakan sarana pengembangan ilmu pengetahuan dan penyebaran kebudayaan ke negara-negara Eropa. Kebudayaan Arab saat ini lebih bersinar daripada peradaban Eropa. Bahasa Arab mampu menghilangkan kebodohan dan memotivasi dunia Islam untuk berkembang dan bangkit. ${ }^{7}$

Pembelajaran bahasa Arab adalah pembelajaran yang menekankan pada keterampilan berbahasa yaitu keterampilan menyimak, berbicara, membaca dan menulis. Kemampuan untuk memahami pembicaraan orang lain disebut kemampuan reseptif selain itu kemampuan ini juga bisa digunakan untuk memahami bacaan. Kemampuan produktif yaitu kemampuan menggunakan bahasa sebagai alat komunikasi baik secara lisan maupun tulis. Kemampuan berbahasa Arab serta sikap positif terhadap bahasa Arab tersebut sangat penting dalam membantu memahami sumber ajaran Islam yaitu al-Qur'an dan al-hadits, serta kitab-kitab berbahasa Arab yang berkenaan dengan Islam bagi peserta didik.

Pembelajaran bahasa Arab diajarkan secara intergral, yaitu dengan menyimak, berbicara, membaca, dan menulis sebagai persiapan untuk mencapai dan mewujudkan pencapaian kompetensi berbahasa. Kecakapan menyimak dan berbicara sebagai landasan berbahasa merupakan titik dasar, pada tingkat pendidikan dasar (elementary). Kemudian keempat kecakapan berbahasa diajarkan secara seimbang pada tingkat pendidikan menengah (intermediate). Agar peserta didik mampu untuk mengakses

4 Wina Sanjaya, Kurikulum Pembelajaran (Jakarta: Prenada Media Group, 2008), hal. 208

5 Atabik Ali dan Zuhdi Muhdlor, Kamus Kontemporer Arab Indonesia (Yogyakarta: Multi Karya Grabika, 1998), hal.1313

6 'Abd al-Hafizh Muhammad Salamah, Tashmim al-Tadris (Riyadh: Daar al-Khariji, 2003), hal. 15

7 'Abd al-'Alim Ibrahim, al-Muwajjih al-Fanni li Mudarrisi al-Lughah al-'Arabiyyah (Kairo: Dâr alMa'arif, tt.), hal. 48 
berbagai referensi berbahasa Arab maka pada tingkat pendidikan lanjut (advanced) dikonsentrasikan pada kecakapan membaca dan menulis. ${ }^{8}$ Kata ini mengandung arti proses interaksi antara lingkungan, hal-hal yang berkaitan dengan pembelajaran, dan respons siswa. ${ }^{9}$

Pembelajaran bahasa Arab termasuk dalam kurikulum pendidikan agama. Bahan ajar yang dipakai adalah sesuai dengan Kurikulum 2013. Tujuan dalam pembelajaran bahasa Arab adalah untuk mendorong, membimbing, mengembangkan kemampuan, serta menumbuhkan sikap positif terhadap bahasa Arab. Mata pelajaran bahasa Arab memiliki tujuan sebagai berikut:

a. Mengembangkan kemampuan berkomunikasi bahasa Arab, baik lisan maupun tulis. Yang mencakup empat kecakapan berbahasa, yakni menyimak (istima'), bericara (kalam), membaca (qira'ah), menulis (kitabah).

b. Dalam mengkaji sumber-sumber ajaran islam, menumbuhkan kesadaran tentang peningnya berbahasa Arab sebagai salah satu bahasa asing untuk menjadi alat utama belajar, khususnya.

c. Mengembangkan pemahaman tentang saling keterkaitan antara bahasa budaya serta memeperluas cakrawala budaya. Dengan demikian, peserta didik diharapkan memiliki wawasan lintas budaya dan melibatkn diri dalam keberagaman budaya. ${ }^{10}$

Berdasarkan uraian di atas dapat disimpulkan bahwa pembelajaran bahasa arab merupakan kegiatan belajar-mengajar yang telah dibuat sesuai sistem yang ada upaya membantu siswa meningkatkan sikap positif terhadapap bahasa Arab dan kemampuan berbahasa tidak hanya pada tulisan, namun juga membaca, mendengar, dan mengucapkannya.

\section{Pendekatan Dalam Pembelajaran Bahasa Arab}

Pengajaran bahasa Arab berkait erat dengan aspek-aspek pengajarannya itu sendiri yang mencakup pendekatan (Approach), metode (method), dan tekhniktekniknya (technique). Serangkaian asumsi hakikat bahasa dan pembelajaran bahasa menurut Edward M. Anthony merupakan sebuah pendekatan dalam pengajaran bahasa Arab. Asumsi yang berhubungan dengan pembelajaran bahasa mencakup aspek mendengar/menyimak (al-Istima'), bercakap-cakap (al-kalam), membaca (alqiraat), dan menulis (al-kitabah). Empat keterampilanini selanjutnya akan membangun metode-metode atau model-model dalam pengajaran bahasa Arab. ${ }^{11}$

8 Peraturan Menteri Agama Indonesia Nomor tahun 2013 tentang Kurikulum 2013 Mata Pelajaran Pendidikan Agama Islam dan Bahasa Arab di Madrasah, hal. 37

9 'Abd al-Habizh Muhammad Salamah, op. cit., hal. 16

10 Peraturan Menteri Agama Indonesia, op.cit. hal. 37

11 Prof. Dr. Sofyan Sauri, M.Pd, Pengembangan Model Pembelajaran Bahasa Arab dengan Metode All In One System di MAN Darussalam Ciamis, Lecture UPI, 2016. 
Approach atau pendekatan ialah sekumpulan assumsi mengenai hakikat bahasa dan pengajaran bahasa serta belajar bahasa. Jadi approach karena merupakan sebuah keyakinan atau pandangan filosofis tentang fitrah bahasa, maka pada hakikatnya approach tersebut merupakan praduga (asummsi) yang secara teoritis dianggap kebenaran umum yang tidak usah dibuktikan lagi meskipun mungkin timbul perbincangan dalam hal meninjau efektifitas dari suatu metode yang lahir dari suatu approach. $^{12}$

Maka, untuk membentuk pembelajaran yang aktif dan untuk mencapai tujun pembelajaran dibutuhkan percobaan dalam rangka memilih pendekatanyang sesuai dengan materi yang diajarkan. Karena tidak semua meteri yang diajarkan cocok dan sesuai dengan pendekatan yang ada.

Berikut pendekatan-pendekatan dalam pengajaran bahasa Arab:
a. Pendekatan Komprehensif
b. Pendekatan Skills
c. Pendekatan Komunikatif
d. Pendekatan Fungsional ${ }^{13}$

Dari ke empat pendekatan tersebut, masing-masing pendekatan memilikiti tata cara dan tujuan sendiri. Dengan mengetahui tata cara pelaksanaan dan mengetahui fokus tujuan yang ingin dicari dengan pendekatan tersebut maka pengajar bahasa Arab akan bisa memilih pendekatan yang akan digunakan.

\section{Keterampilan Berbahasa}

a. Keterampilan mendengar (Maharat al-Istima')

Keterampilan mendengar (Maharat al-Istima') merupakan keterampilan awal dalam pembelajaran bahasa, baik bahasa ibu maupun bahasa asing termasuk di dalamnya adalah bahasa Arab. ${ }^{14}$ Dengan demikian kegagalan dalam pembelajaran keterampilan ini dapat mengakibatkan kegagalan pada pembelajaran keterampilanketerampilan bahasa berikutnya.

Istima' merupakan kumpulan fitur bunyi yang terkandung dalam mufrodat. Keterampilan Istima' diarahkan pada keterampilan menyimak dengan tidak melepas konteks. Mendengar merupakan keterampilan pertama yang dilakukan oleh seseorang dalam belajar berbahasa. Menyimak dapat menjadi alat ukur tingkat kesulitan yang dialami oleh seseorang yang belajar bahasa, karena dari keterampilan ini maka kita bisa tahu pemahaman dialeknya, pola pengucapannys, struktur bahasa

12 Tim Penyusun Buku Pedoman Bahasa Arab Direktorat Jendral Bimbingan Masyarakat Islam, Pedoman Pengajaran Bahasa Arab, (Jakarta, Dirjes Bimas Islam, 1976), hal. 91

13 Dr. Ahmad 'Abd, Madakhil Ta'lim Al-Lughah Al 'arabiyyah, (Makkah, 2000 M).

14 Abdullah bin Ahmad Al-Fakihy, Syarh Fawakih al-Haniyah (Semarang: Maktabah Usaha Keluarga Semarang, tt), hal. 12 
dan lain sebagainya. ${ }^{15}$ Dan keterampilan ini merupakan keterampilan dasar yang dibutuhkan oleh pelajar bahasa Arab.

\section{b. Keterampilan berbicara (Maharat al-Kalam)}

Keterampilan berbicara (maharat al-kalam) adalah kelanjutan dari keterampilan mendengar. Kedua keterampilan ini saling terkait. Orang yang pendengarannya baik dimungkinkan untuk dapat berbicara dengan baik pula, sebaliknya orang yang tidak dapat mendengar dengan baik tidak akan dapat berbicara dengan baik. Oleh karena itu pengajar bahasa bisa melaksanakan pembelajaran keterampilan berbicara seraya mengiringi keterampilan mendengar yang telah dimiliki peserta didik. Pemahaman peserta didik tentang topik bahasan yang diperolehnya melalui proses mendengar dapat dimanfaatkan sebagai langkah awal pengajaran berbicara. ${ }^{16}$

Untuk menunjang lebih berkembangnya pelajar bahasa Arab dalam pembelajaran, maka tidaklah cukup dengan kemampuan menyimak saja. Namun setelah mendapatkan kemampuan menyimak dengan baik pelajar bahasa Arab harus bisa menirukan apa yang dia dengar dengan cara mengungkapkan apa yang telah didapat dalam keterampilan menyimak. Dengar keterampilan berbicara maka pelajar akan menjadi subjek yang lebih aktif dalam pelaku bahasa.

\section{c. Keterampilan Membaca (Maharat al-Qira'at)}

Dalam hal pemberian butir linguistic keterampilan membaca memiliki kelebihan dari keterampilan menyimak, karena keterampilan membaca lebih akurat dari pada keterampilan menyimak. Seseorang yang sedang belajar ketrampilan membaca bisa mendapatkan pembelajaran dari majalah, buku, dan surat kabar yang berbahasa Arab. Dengan begitu pembelajar akan memperoleh tambahan kosa kata dan bantuk bahasa lain dalam jumlah banyak yang bermanfaat dalam berinteraksi secara komunikatif. ${ }^{17}$

Seperti halnya keterampilan menyimak, keterampilan membaca merupakan usaha dari seseorang untuk lebih menambah kosa kata dan memperluas wawasan dalam pembelajaran bahasa Arab. Agar lebih memahami ilmu kebahasaan maka pemahaman dan kosa kata secara sistematis didapat dari litelatur-litelatur yang menggunakan bahasa Arab, dan untuk mendapatkannya maka perlu keterampilan lanjutan yang disebut keterampilan membaca, dalam al ini membaca litelatur yang berbahasa Arab.

\section{d. Keterampilan menulis (Maharat al-Kitabah)}

Keterampilan menulis (Maharah al-Kitabah) merupakan keterampilan terakhir dalam beberapa keterampilan bahasa. ${ }^{18}$ Untuk menguasai keterampilan ini secara

15 Taufik, op.cit, hal, 45

16 Abd Rahman bin alFauzan dkk, Al-Arabiyyah Bayn Yadayk (Riyadh: Muassasah al-Waqf alIslamy, 2002), hal. 12

17 Taufik, op.cit, hal. 53

18 Juwairiyah Dahlan, Metode Belajar Mengajar Bahasa Arab, (Surabaya: Al-Ikhlas, 1992), hal 59. 
baik dibutuhkan penguasaan keterampilan bahasa sebelumnya dengan baik pula. Hal ini dikarenakan menulis merupakan kegiatan menuangkan isi pikiran dalam bentuk tulisan yang tujuannya untuk dapat dipahami oleh pembaca yang tentu saja tidak sedang berhadapan atau bahkan tidak satu masa dengan penulis. Seluruh aspek bahasa yang meliputi penguasaan struktur (qawâ’id), kosa kata (mufradât), sastra (balâghah), dan pilihan diksi yang baik (ikhtiyâr alkalimah) sangat dibutuhkan dalam kegiatan menulis. ${ }^{19}$

Setelah memperoleh ketiga keterampilan bahasa yaitu keterampilan mentimak, bicara dan membaca maka, keterampilan menulis merupakan keterampilan yang paling tinggi tingkat kesulitannya. Selain membutuhkan penguasaan dari seluruh keterampilan yang ada dalam keterampilan menulis juga membutuhkan penguasaan dalam seluruh aspek kebahasaan seperti qawầid dan semua unsur yang telah disebutkan di atas.

\section{Metode Penelitian}

Penelitian ini merupakan penelitian lapangan(field reseach) dengan menggunakan metode deskriptif kualitatif. Penelitian deskriptif kualitatif merupakan penelitian secara mendalam dan ikut berpartisipasi dalam lapangan dan situasi nyata. ${ }^{20}$ Penelitian ini dilakukan semata-mata berdasarkan pada fakta yang ada atau fenomena yang secara empiris terjadi di beberapa lapangan. Data penelitiannya merupakan data kualitatif mengenai gambaran pembelajaran bahasa Arab jika diterapkan di beberapa sekolah. Maka dari itu tulisan ini merujuk pada sumber-sumber berupa buku dan jurnal ilmiah yang tentunya berkaitan dengan pokok permasalahan.

\section{Hasil dan Pembahasan}

\section{Konsep Pembelajaran Komprehensif}

Pendekatan komperhensif mengacu kepada fungsi bahasa bagi manusia. Jack C.Richards menguraikan bahwa bahasa memiliki tiga fungsi utama, yaitu: (1) deskriptif, (2) ekspresif, dan (3) sosial. Fungsi deskriptif bahasa adalah untuk menyampaikan informasi faktual. Fungsi ekspresif ialah memberi informasi keadaan pembicara itu sendiri, mengenai perasaan-perasaannya, kesenangannya, prasangkanya, dan pengalaman-pengalaman yang telah lewat. Sedangkan fungsi sosial bahasa ialah melestarikan hubungan-hubungan sosial antar manusia.

Pelaksanaan pengajaran intensif yang dilaksanakan oleh jurusan bahasa pada umumnya berhasil mengantarkan lulusannya menguasai bahasa asing baik lisan maupun tulisan secara baik dan mendalam, baik dari sisi gramatika, komunikasi, bacaan maupun sampai tingkat kemampuan mendengar. Pengajaran bahasa Arab

19 Rusydy Ahmad Tho'imah, Ta'lim alLughah al-Arabiyyah li Ghayr al-Nâthiqîn Bihâ Manahijuhu wa Asalibuhu. (Riyadh: Ayisku, 1989), hlm. 78. Baca juga Thoha Aly Husien al-Dalmy, Al-Lughah al'Arabiyyah; Manâhijuhâ wa Tharâiq Tadrîsihâ (Baghdad: Jami'ah al-Hasyimiyah,tt), hal. 45.

20 Boy S. Sabarguna, Analisis Data Pada Penelitian Kualitatif, (Jakarta: UI-Pres, 2008), hal. 4 
dengan model pendekatan alamiah atau tradisional seperti yang dikembangkan di pondok-pondok pesantren umumnya hanya bisa mengantarkan peserta didik menguasai bahasa secara pasif, yaitu mampu memahami beberapa kitab standar yang telah ditetapkan oleh pondok pesantren tetapi umumnya mereka mengalami kesulitan dalam berkomunikasi lisan. Hasilnya kemudian adalah mereka paham bahasa Arab tetapi tidak mampu mengkomunikasikannya, padahal berbahasa itu pada hakekatnya adalah mengekspresikan kemampuan lisan.

Pengajaran bahasa Arab yang dilakukan bersamaan dengan pengajaran bidang studi lainnya, pada umumnya hasilnya kurang memuaskan. Dalam arti bahwa hasil proses belajar mengajar dengan model pendekatan ini seringkali memberikan hasil yang setengah-setengah. Akibatnya, setelah mereka keluar dari jalur pendidikan yang mereka tempuh, kemampuan mereka tidak bisa diandalkan. Kenyataan ini tidak hanya terjadi pada pendidikan dasar dan menengah Islam, tetapi juga pada jenjang perguruan tinggi Islam.

Berdasarkan fakta di atas, maka diperlukan sebuah bentuk kajian dalam pengajaran bahasa Arab yang lebih kreatif dan mencerdaskan, yang tidak saja melahirkan orang-orang yang ahli dalam berkomunikasi dalam bahasa Arab, namun juga melahirkan ahli-ahli dalam menulis, membaca dan memahami bahasa Arab. Pengembangan metode pengajaran bahasa Arab hanya dapat dilakukan oleh seorang guru yang kreatif dan inovatif yang selalu memperhatikan prinsip-prinsip pengajaran bahasa dan mampu mengumpulkan gagasan/ide untuk diramu dari hal-hal yang biasa menjadi luar biasa. ${ }^{21}$ Dan untuk melakukan hal tersebut maka menggunakan pendekatan dan metode yang sesuai dan paling efektif pada setiap materi yang diajarkan.

Beberapa langkah dalam pembelajaran komperhensif antanya:

\section{a. Rencana Pembelajaran}

Rencana pembelajaran komprehensif berisi komponen-komponen yang sama dengan rencana pembelajaran sebagaimana digunakan di sekolah yang biasa disebut (RPP), tetapi memiliki spesifikasi untuk mengajarkan tema atau topik Bahasa Arab yang menekankan kepada keterampilan berbahasa.

Keterampilan dalam berbahasa mencakup empat keterampilan, yaitu keterampilan mendengar (Maharat al-Istima'), keterampilan berbicara (Maharat alKalam), keterampilan membaca (Maharat al-Qira'at), dan keterampilan menulis (Maharat al-Kitabah). Keempat aspek ini menjadi aspek penting dalam pembelajaran bahasa Arab, karena keempat keterampilan tersebut tidak dapat dipisahkan. Kedudukan keempat keterampilan ini sangat menunkang dalam pencapaian keterampilan berbahasa. ${ }^{22}$

21 Yufridal Fitri Nur Salam, SIgnifikansi Pendekatan All In One System Pada Keterampilan Bahasa Arab, Cendekia: Jurnal Pendidikan dan Kemasyarakatan, 2011.

22 Taufik, op.cit, hal. 43 
Ada enam komponen dari rencana pembelajaran, yaitu:

1. Tema/topik, berisi nama tema/topik yang akan diajarkan. Tema/topik tersebut diambil dari kurikulum (silabus) bahasa Arab pada semester yang sesuai dengan pembelajaran keterampilan berbahasa.

2. Tujuan pembelajaran, merupakan sasaran yang akan dicapai dalam pembelajaran. Tujuan tersebut berisi rumusan kompetensi yang diharapkan dikuasai oleh para siswa. Tujuan pembelajaran umum, berisi rumusan kompetensi dasar berkenaan dengan topik yang diajarkan, sedang tujuan pembelajaran khusus, berisi rumusan-rumusan indicator dari topik yang akan diajarkan.

3. Materi Pembelajaran, merupakan isi atau substansi bahan yang akan diajarkan, yang menunjang penguasaan kompetensi yang menjadi tujuan pembelajaran. Materi pembelajaran ini hanya memuat garis-garis besar bahan ajaran yang merupakan rincian dari topik pembelajaran.

4. Model pembelajaran, berisi rumusan tentang model pembelajaran komprehensif dengan variasi metode yang akan digunakan. Jenis metode yang digunakan dalam setiap pertemuan tidak selalu sama, disesuaikan dengan topik dan kompetensi yang akan dicapai. Metode-metode tersebut pada umumnya merupakan metode yang berisi kegiatan yang mengaktifkan siswa.

5. Media dan Sumber Pembelajaran, berisi rumusan tentang media atau alat bantu pembelajaran, berisi rumusan tentang media atau alat bantu pembelajaran yang digunakan untuk membantu memperjelas atau mempermudah penguasaan materi atau kompetensi yang ingin dicapai. Media pembelajaran dapat menggunakan media yang sudah ada di sekolah atau diadakan oleh guru dan siswa. Sumebr pembelajaran dapat berupa buku, majalah, dan bahan cetak lain, bahan elektronik, orang, atau nara sumber dan sumebr pembelajaran yang ada di lingkungan masyarakat.

6. Evaluasi Pembelajaran, merupakan kegiatan untuk mengukur dan menilai pencapaian tujuan yang telah dirumuskan. Evaluasi ini meliputi evaluasi proses dan evaluasi hasil pembeajaran. Evaluasi proses ditujukan untuk menilai perilaku atau keterampilan siswa dalam berbagai kegiatan pembelajaran. Evaluasi hasil ditujukan untuk mengukur dan menila tingkat penguasaan siswa dan materi yang dirumuskan dalam tujuan.

\section{b. Prosedur Pembelajaran}

Prosedur pembelajaran berisi langkah-langkah umum dan rincian singkat dari metode atau pendekatan komprehensif. Prosedur ini dibuat untuk membantu mempermudah guru dalam menguasai dan melaksanakan langkah-langkah pembelajaran menyeluruh dan komprehensif. Dalam prosedur ini ada empat 
langkah utama, yaitu: orientasi, eksplorasi, pendalaman, dan penyimpulan. Langkah orientasi berisi kegiatan pengenalan dan pengondisian; langkah eksplorasi berisi kegiatan menyimak penjelasan, membaca, mendengarkan, berbicara, dan menulis; langkah pemantapan berisi kegiatan tanya jawab, diskusi kelas, tes tertulis dan tes lisan. Langkah penyimpulan berisi kegiatan: pembutaan kesimpulan dan pemberian tugas.

\section{c. Implikasi dalam Pembelajaran Bahasa Arab}

Pelaksanaan pembelajaran merupakan langkah implementasi dari rencana pembelajaran komprehensif berisi rincian dari prosedur pembelajaran. Sama dengan pada prosedur ada empat langkah utama yang merupakan sintaks dari pendekaran komprehensif, yaitu langkah orientasi, eksplorasi, pemantapan dan penyimpulan.

1. Langkah Orientasi atau kegiatan awal pembelajaran merupakan langkah untuk mendorong kelas memusatkan perhatian terhadap pembelajaran. Langkah ini berisi kegiatan:

a. Apersepsi atau menghubungkan materi baru dengan yang sudah dikuasai.

b. Pengondisian kelas berisi penciptaan situasi, pemberian motivasi dan penjelasan tentang langkah-langkah pembelajaran yang akan dilakukan.

2. Langkah eksplorasi, atau kegiatan inti pertama yang merupakan langkah untuk mengajak dan mendorong siswa untuk mengajak dan mendorong siswa untuk mengembangkan keterampilan berbahasa, yaitu keterampilan mendengar, berbicara, membaca, dan menulis.

3. Langkah pemantapan, kegitaan inti kedua merupakan langkah untuk memperdalam, memperluas, memantapkan, memperkuat penguasaan materi dan kemampuan yang telah dicapai pada langkah eksplorasi. Kegiatan-kegiatan utama yang dilakukan pada langkah ini adalah:

\section{a. Kegiatan Dalam Keterampilan Mendengar (Maharat al-Istima')}

Keterampilan mendengar (Maharat al-Istima') merupakan keterampilan awal dalam pembelajaran bahasa, baik bahasa ibu maupun bahasa asing termasuk di dalamnya adalah Bahasa Arab. ${ }^{23}$ Dengan demikian kegagalan dalam pembelajaran keterampilan ini dapat mengakibatkan kegagalan pada pembelajaran keterampilanketerampilan bahasa berikutnya.

Istima' merupakan kumpulan fitur bunyi yang terkandung dalam mufrodat. Keterampilan Istima' diarahkan pada keterampilan menyimak dengan tidak melepas konteks. Mendengar merupakan keterampilan pertama yang dilakukan oleh seseorang dalam belajar berbahasa. Menyimak dapat menjadi alat ukur tingkat

23 Abdullah bin Ahmad Al-Fakihy, Syarh Fawakih al-Haniyah (Semarang: Maktabah Usaha Keluarga Semarang, tt), hal. 12 
kesulitan yang dialami oleh seseorang yang belajar bahasa, karena dari keterampilan ini maka kita bisa tahu pemahaman dialeknya, pola pengucapannys, struktur bahasa dan lain sebagainya. ${ }^{24}$ Dan keterampilan ini merupakan keterampilan dasar yang dibutuhkan oleh pelajar bahasa Arab.

\section{b. Kegiatan Dalam Keterampilan Berbicara (Maharat al-Kalam)}

Keterampilan berbicara (maharat al-kalam) adalah kelanjutan dari keterampilan mendengar. Kedua keterampilan ini saling terkait. Orang yang pendengarannya baik dimungkinkan untuk dapat berbicara dengan baik pula, sebaliknya orang yang tidak dapat mendengar dengan baik tidak akan dapat berbicara dengan baik. Oleh karena itu pengajar bahasa bisa melaksanakan pembelajaran keterampilan berbicara seraya mengiringi keterampilan mendengar yang telah dimiliki peserta didik. Pemahaman peserta didik tentang topik bahasan yang diperolehnya melalui proses mendengar dapat dimanfaatkan sebagai langkah awal pengajaran berbicara. ${ }^{25}$

Untuk menunjang lebih berkembangnya pelajar bahasa Arab dalam pembelajaran, maka tidaklah cukup dengan kemampuan menyimak saja. Namun setelah mendapatkan kemampuan menyimak dengan baik pelajar bahasa Arab harus bisa menirukan apa yang dia dengar dengan cara mengungkapkan apa yang telah didapat dalam keterampilan menyimak. Dengar keterampilan berbicara maka pelajar akan menjadi subjek yang lebih aktif dalam pelaku bahasa.

\section{c. Kegiatan Dalam Keterampilan Membaca (Maharat al-Qira'at)}

Dalam hal pemberian butir linguistic keterampilan membaca memiliki kelebihan dari keterampilan menyimak, karena keterampilan membaca lebih akurat dari pada keterampilan menyimak. Seseorang yang sedang belajar ketrampilan membaca bisa mendapatkan pembelajaran dari majalah, buku, dan surat kabar yang berbahasa Arab. Dengan begitu pembelajar akan memperoleh tambahan kosa kata dan bantuk bahasa lain dalam jumlah banyak yang bermanfaat dalam berinteraksi secara komunikatif. ${ }^{26}$

Seperti halnya keterampilan menyimak, keterampilan membaca merupakan usaha dari seseorang untuk lebih menambah kosa kata dan memperluas wawasan dalam pembelajaran bahasa Arab. Agar lebih memahami ilmu kebahasaan maka pemahaman dan kosa kata secara sistematis didapat dari litelatur-litelatur yang menggunakan bahasa Arab, dan untuk mendapatkannya maka perlu keterampilan lanjutan yang disebut keterampilan membaca, dalam al ini membaca litelatur yang berbahasa Arab.

24 Taufik, op.cit, hal, 45

25 Abd Rahman bin alFauzan dkk, Al-Arabiyyah Bayn Yadayk (Riyadh: Muassasah al-Waqf alIslamy, 2002), hal. 12

26 Taufik, op.cit, hal. 53 


\section{d. Kegiatan Dalam Keterampilan Menulis (Maharat al-Kitabah)}

Keterampilan menulis (Maharah al-Kitabah) merupakan keterampilan terakhir dalam beberapa keterampilan bahasa. ${ }^{27}$ Untuk menguasai keterampilan ini secara baik dibutuhkan penguasaan keterampilan bahasa sebelumnya dengan baik pula. Hal ini dikarenakan menulis merupakan kegiatan menuangkan isi pikiran dalam bentuk tulisan yang tujuannya untuk dapat dipahami oleh pembaca yang tentu saja tidak sedang berhadapan atau bahkan tidak satu masa dengan penulis. Seluruh aspek bahasa yang meliputi penguasaan struktur (qawâ’id), kosa kata (mufradât), sastra (balâghah), dan pilihan diksi yang baik (ikhtiyâr alkalimah) sangat dibutuhkan dalam kegiatan menulis. ${ }^{28}$

Setelah memperoleh ketiga keterampilan bahasa yaitu keterampilan mentimak, bicara dan membaca maka, keterampilan menulis merupakan keterampilan yang paling tinggi tingkat kesulitannya. Selain membutuhkan penguasaan dari seluruh keterampilan yang ada dalam keterampilan menulis juga membutuhkan penguasaan dalam seluruh aspek kebahasaan seperti qawâ'id dan semua unsur yang telah disebutkan di atas.

a. Langkah penyimpulan, Langkah untuk menyimpulkan atau merangkumkan dan menegaskan tentang apa yang telah dipelajari merupakan langkah akhir atau kegiatan akhir pembelajaran, yang berisikan kegiatan-kegiatan sebagai berikut:

a) Guru menyimpulkan materi dan kemampuan yang telah dipelajari dan dilatihkan.

b) Guru menegaskan pentingnya materi dan kemampuan yang telah dipelajari dalam pendidikan dan kehidupan yang akan datang.

\section{Faktor Pendukung Model Pembelajaran Komprehensif}

Efektifitas pembuatan rancangan dan implementasi model pembelajaran ini sangat didukung oleh berbagai faktor sebagai berikut:

a) Guru; berkenaan dengan kemapanan guru dalam berbagai aspek, di antaranya kualifikasi pendidikan, potensi dan kondisi, persepsi terhadap profesi dan tugas mengajar serta kemampuan dan kecakapan menyelenggarakan serta mengelola pembelajaran yang sesuai dengan karakteristik model pembelajaran.

b) Siswa; berkenaan dengan karakteristik, potensi, minat, kemampuan dan persepsinya terhadap pembelajaran kooperatif serta pelajaran Bahasa Arab.

27 Juwairiyah Dahlan, Metode Belajar Mengajar Bahasa Arab, (Surabaya: Al-Ikhlas, 1992), hal 59.

28 Rusydy Ahmad Tho'imah, Ta'lim alLughah al-Arabiyyah li Ghayr al-Nâthiqîn Bihâ Manahijuhu wa Asalibuhu. (Riyadh: Ayisku, 1989), hlm. 78. Baca juga Thoha Aly Husien al-Dalmy, Al-Lughah al'Arabiyyah; Manâhijuhâ wa Tharâiq Tadrîsihâ (Baghdad: Jami’ah al-Hasyimiyah,tt), hal. 45. 
c) Guru bertugas untuk menyediakan atau mempasilitasi sumber belajar, media danalatbantu belajar, berkenaan denganketersediaan, keberfungsian dan kreatifitas penyajian dan pemanfaatanya.

d) Ukuran, kondisi dan suasana kelas; Ukuran berkaitan dengan luas dan pemanfaatan ukuran kelas; kondisi kelas berkenaan dengan penataan sarana dan prasarana di kelas sehingga kondusif untuk pembelajaran kooperatif.

e) Waktu; Untuk mengetahui keefektivitasan dari implementasi model pembelajaran kooperatif maka membutuhkan waktu yang memadai dengan pemanfaatan yang optimal dan bermakna.

\section{Kelebihan Model Pembelajaran Komprehensif Yang Dihasilkan}

Model pembelajaran komprehensif hasil pengembangan memiliki kelebihan dibandingkan dengan model pembelajaran biasa dalam dua aspek yang menjadi sasaran pembelajaran, yaitu penguasaan: keterampilan sosial dan pengetahuan.

Perbedaantingkatpenguasaanyangcukupberartidarihasil tesakhirdibandingkan dengan hasil tes awal, baik dalam aspek keterampilan sosial maupun pengetahuan bahasa Arab merupakan kelebihan dari model pembelajaran komprehensif.

\section{a. Penguasaan keterampilan berbahasa Arab}

a) Setelah belajar dengan menggunakan pendekatan komprehensif, penguasaan keterampilan berbahasa lebih tinggi. Skor rata-rata (mean) hasil tes akhir lebih besar dan berbeda secara signifikan dibandingkan dengan hasil tes awal.

b) Perbedaan tersebut diperkuat oleh hasil uji perbedaan dengan kelompok kontrol. Perbedaan yang sangat berarti didapatkan dalam setiap pasangan sekolah eksperimen dengan sekolah sosial perbedaan itu berupa hasil skor rata-rata keterampilan sosial dari sekolah-sekolah kelompok eksperimen lebih tinggi dari rata-rata skor sekolah kelompok kontrol, dengan

c) Pendekatan komprehensif memberikan hasil lebih baik dalam pengembangan keterampilan berbahasa Arab, di antaranya karena menggunakan berbagai variasi kegiatan pembelajaran kelompok sehingga banyak memberikan kesempatan untuk berlatih keterampilan berbahasa Arab. Hal itu berarti bahwa pendekatan komprehensif cocok digunakan untuk pengembangkan keterampilan berbahasa Arab.

d) Implementasi pendekatan komprehensif memberikan dampak yang beragam (variatif) terhadap keterampilan berbahasa Arab siswa, hal ini menunjukkan keevektifitasan dari pendekatan kooperatif terutama pada siswa dari sekolah kategori menengah. Sehingga bisa disimpulkan 
bahwa model pembelajaran kooperatif ini memiliki kesesuaian yang baik, sehingga dapat digunakan pada berbagai tingkat kemampuan siswa.

\section{b. Penguasaan pengetahuan Bahasa Arab}

a) Perbedaan yang sangat berarti antara tes awal (peost test) dengan tes akhir (post test) menunjukkan perbedaan dalam aspek pengetahuan sebagai dampak pengiring dari pembelajaran aspek keterampilan, sekolah-sekolah yang menjadi kelompok eksperimen.

b) Perbedaan tersebut diperkuat oleh hasil uji perbedaan dengan kelompok control. Dalam setiap pasangan sekolah eksperimen dengan sekolah sosial diperoleh hasil bahwa skor rata-rata sekolah-sekolah dari kelompok eksperimen (yang menggunakan model pembelajaran komprehensif) hasilnya lebih tinggi dari skor rata-rata sekolah kelompok kontrol (yang menggunakan model pembelajarn biasa), dan perbedaannya sangat signifikan atau berarti.

c) Penguasaan hasil belajar pada aspek pengetahuan lebih homogen dibandingkan dengan dalam aspek keterampilan berbahasa Arab.

d) Penggunaan model pembelajaran kooperatif cenderung memberi keragaman hasil dalam aspek pengetahuan hal ini bisa dilihat dari Tingkat heterogenitas pencapaian aspek pengetahuan cenderung lebih menonjol pada kelompok eksperimen dibanding kelompok kontrol.

e) Model pembelajaran komprehensif lebih unggul dari pembelajaran biasa karena para siswa banyak melakukan variasi kegiatan dibandingkan dengan pembelajaran biasa. Melalui berbagai variasi kegiatan belajar tersebut mereka melakukan pengulangan, perluasan, pendalaman dan penguatan terhadap penguasaan materi pengetahuan yang dipelajari, sedang dalam pembelajaran biasa yang bersifat ekspositori, siswa hanya mengalami atau melakukan satu atau dua kegiatan belajar saja, sehingga tidak atau kurang terjadi pengulangan, perluasan, pendalaman dan penguatan penguasaan.

\section{Hambatan dan Optimalisasi Pelaksanaan}

Ada beberapa hambatan yang dihadapi dalam pelaksanaan model pembelajaran komprehensif:

a) Pertama, karena belum biasa guru tidak langsung dapat melaksanakan pendekatan komprehensif secara efektif, mereka membutuhkan penyesuaian atau latihan dalam pertemuan pertama, tetapi pada pertemuan berikutnya dapat lebih efektif.

b) Kedua, karena belum biasa para siswa juga membutuhkan waktu untuk menyesuaikan diri dengan kegiatan yang baru. Guru dituntut untuk lebih 
meningkatkan disiplin belajar terutama kebiasaan siswa berbicara dan bekerja lebih efisien.

c) Ketiga, kegiatan-kegiatan yang mengaktifkan siswa membutuhkan waktu belajar yang relatif lebih lama. Masalah ini dapat diatasi dengan meningkatkan efisiensi penggunaan waktu, penentuan target sasaran dan waktu untuk setiap kegiatan, pengawasan dan perintah untuk segera mengakhiri sesuatu kegiatan dan berpindah ke kegiatan lainnya.

d) Keempat, adalah kelengkapan media dan sumber. Masalah ini merupakan masalah umum yang dihadapi oleh sekolah, dapat diatasi dengan meningkatkan kerjasama dengan unsur pimpinan dan komite sekolah, dan peningkatan upaya guru mengembangkan sendiri media dan sumber belajar.

\section{E. Kesimpulan}

Pembelajaran komperhensif adalah pembelajaran yang mengacu kepada fungsi bahasa pada manusia yaitu: deskriptif yaitu sebagai untuk penyampaian informasi secara aktual, ekspresif untuk menyampaikan keadaan dari pembicara, dan sosial yaitu untuk melestarikan hubungan sosial antara manusia. Adapun tahap pembelajarannya adalah meliputi: tahap perencanaan, prosedur pembelajaran dan impikasi dalam pembelajaran yang meliputi langkah orientasi, langkah eksplorasi dan langkah pemantapan. Setelah melewati pembelajaran dengan pendekatan komperhensif ini, maka dapat menigkatkan pemahaman berbahasa siswa.

\section{Daftar Purstaka}

'Abd al-'Alim Ibrahim. Tt. al-Muwajjih al-Fannî li Mudarrisî al-Lughah al-'Arabiyyah. Kairo: Dâr alMa’arif.

Abd al-Hafizh Muhammad Salamah. 2003. Tashmîm al-Tadrîs. Riyadh: Dâr alKhariji.

Abd Rahman bin alFauzan dkk. 2002. Al-Arabiyyah Bayn Yadayk (Riyadh: Muassasah al-Waqf al-Islamy.

Abd Wahab Rosyidi \& Mamlu'atul Ni'mah. 2011. Pembelajaran Bahasa Arab Malang: UIN Maliki Press.

Ali, Atabik dan Zuhdi Muhdlor.1998. Kamus Kontemporer Arab Indonesia Yogyakarta: Multi Karya Grafika.

Aziz, Furqonul. 1996. Pengajaran Bahasa Komunikatif. Bandung: Remaja Roesda Karya.

Dahlan, Juwairiyyah. 1992. Metode Belajar Mengajar Bahasa Arab. Surabaya: Al-Ikhlas. 
Nur Salam, Yufridal Fitri. 2011. SIGNIFIKANSI PENDEKATAN ALL IN ONE SYSTEM PADA KETERAMPILAN BAHASA ARAB. Jurnal Cendekia: Jurnal Pendidikan dan Kemasyarakatan, Vol. 9 No. 11.

Peraturan Menteri Agama Indonesia Nomor tahun 2013 tentang Kurikulum 2013 Mata Pelajaran Pendidikan Agama Islam dan Bahasa Arab di Madrasah

Sanjaya, Wina. 2008. Kurikulum Pembelajaran. Jakarta: Prenada Media Group.

Semi, M. Atsar. 1990, Rancangan Pengajaran Bahasa dan Sastra Indonesia, Bandung: Angkasa.

Taufik. 2011. Pembelajaran Bahasa Arab MI (Metode Aplikatif dan Inovatif berbasis ICT). Surabaya: PMN.

Thoha Aly Husien al-Dalmy. Tt. Al-Lughah al-Arabiyyah; Manahijuha wa Tharaiq Tadrisiha. Baghdad: Jami'ah al-Hasyimiyah.

Tho'imah, Rusydy Ahmad. 1989. Ta'lim alLughah al-Arabiyyah li Ghayr al-Nathiqin Biha Manahijuhu wa Asalibuhu. Riyadh: Ayisku.

Tim Penyusun Buku Pedoman Bahasa Arab Direktorat Jendral Bimbingan Masyarakat Islam, Pedoman Pengajaran Bahasa Arab. Jakarta: Dirjes Bimas Islam. 1976.

Usup Supriatna. 2016. PENGEMBANGAN MODEL PEMBELAJARAN KOMPREHENSIF DALAM PENDIDIKAN ILMU PENGETAHUAN SOSIAL DI SEKOLAH DASAR. JINoP (Jurnal Inovasi Pembelajaran), Vol.2 No.1. 